\title{
THE PERCEPTION OF AGRICULTURAL EXTENSION AGENTS ON JOB MOTIVATION IN KWARA STATE NIGERIA
}

Adesiji G.B., Komolafe S.E., Ifabiyi J.O., Ajibola B.O. and Animashaun J.O.

Department of Agricultural Extension and Rural Development, University of Ilorin, PMB 1515, llorin, Nigeria

Department of Agricultural Economics and Farm Management, University of llorin, PMB 1515, Ilorin, Nigeria

Corresponding author: kemmas04@yahoo.com

\begin{abstract}
This study examined extension agent perception on job motivation in Kwara State, Nigeria. The study engaged the entire 106 agricultural extension agents in Kwara State. Data were analysed using both Descriptive Statistics and Pearson Product Moment Correlation (PPMC). Results showed that the major perceived motivating factors among extension agents in Kwara State in descending order were the following: supervision of work, recognition for good work, feedback from supervision, evaluation of work, salary increment, meeting with supervisor, promotion prospect, annual leave opportunity, payment of salary at the right time, and good housing opportunity while motivation by pay than money was considered as a minor motivating factor. The PPMC result showed that significant determinants of job motivation were age $(P=0.025)$, gender $(P=0.032)$, education (0.025), and experience $(P=0.032)$ at $P \leq 0.05$. The study recommended among others that the members of staff who perform supervisory roles in the organization should be given more training that places more emphasis on supervision.
\end{abstract}

Keywords: perception, job motivation, extension agent, Kwara state, Nigeria

\section{INTRODUCTION}

Agricultural Extension Services are long time efforts through which research institute reach farmers in Nigeria. Extension has been contributing effectively in terms of advisory services and education of farmers with regard to stable food production in Nigeria (Olagunju and Adesiji, 2006). The effectiveness of job performance by agricultural extension agents can be enhanced when they are well motivated. As noted by Mojoyinola (2000), that the determinants to one's action (motivation) predict one's ability. Ifenkwe, (2012) had also stated that good extension programmes do not yield positive results, unless they are executed by a good number of energetic and motivated staff. Haile and Abebew (2012) further stressed that motivation of agricultural extension agents will determine their effectiveness.

The necessity to motivate agricultural extension agents in Nigeria has been highlighted by 
literatures. Madukwe (1996) stated that the performance of extension services has been, generally unsatisfactory because of the way staff members carry out their supervisory roles. The need to expand the roles of extension in response to the challenges in the contemporary realities of a deregulated economy of the country was also emphasized by Agbamu, 2005. Akinsorotan and Adesiji (2001) in their view stated that the need to motivate agricultural extension agents is for the overall economic development of the nation. Babu et al. (1997) have identified lack of motivation, experts and job satisfaction as the most important issues of developmental organizations among the agricultural extension sector in developing countries. Banmeke and Ajayi (2005) have reported that the non-availability of facilities necessary for effective implementation and functioning have resulted in low morale and poor performance among agricultural extension workers in Nigeria. Adesiji et al., (2013) concluded that private extension services provider provide better extension services delivery compared to public extension services' provider.

The Agricultural Development Project (ADP) all over Nigeria was established mainly to improve the agricultural productivity of the small-scale farmers through provision of improved production package and provision of infrastructural facilities (Idachaba, 1984). Motivating youth for extension services in the country has been identified as important competencies for extension service delivery (Adefalu et al. 2010). The need to attract and retain competent, (Bakker et al. 2011; Ployhart, 2006) affirmed the need to create work conditions that promote and sustain employee motivation and well-being. The human resources used by ADP are of different cadres of agricultural extension agents such as Village Extension Agents (VEAS) and Block extension supervisors (BES). The need to motivate these agents called for the examination of their perception for job motivation. It was on this note that this study sought to examine the perception of agricultural extension agents on job motivation in Kwara SateADP.

The specific Objectives were to;(i)describe the socio-economic characteristics of extension workers of Kwara State ADP and (ii) identify the perceived job motivation of extension workers of KwaraADP.

The Hypothesis of the study was stated in null form as: there is no significant relationship between selected socio-economic and perceived job motivation factors of extension workers of KwaraADP.

\section{METHODOLOGY}

The study was carried out in Kwara State ADP. Kwara State with the total of sixteen Local GovernmentAreas (LGAs) has a population of 1,566,469 and a total land size of 3682500 hactares (NPC1991, FOS1995). The state is located between latitudes $7^{\circ} 45^{\prime} \mathrm{N}$ and $9^{\circ} 30^{\prime} \mathrm{N}$ and longitude 
$2^{0} 30^{\prime} \mathrm{E} \& 6^{0} 25^{\prime} \mathrm{E}$. The topography is mainly plain to slightly gentle rolling lands. The annual rainfall ranges between $1000 \mathrm{~mm}$ and $1500 \mathrm{~mm}$. Average temperature ranges between $30^{\circ} \mathrm{C}$ and $35^{\circ} \mathrm{C}$. It also has an estimated figure of 203,833 farm families with the majority living in the rural area.

The population for this study comprised all (106) extension workers of Kwara State ADP in all the four zones tagged $A, B, C$ and $D$. The entire 106 extension agents in the study area were used for this study. A structured questionnaire was developed, protested, validated. It wasused to obtain information on the specific objectives stated above from all the 106 extension workers of Kwara ADP in the four zones within the period of June, 2009 to July, 2009.

To find out the major perceived motivating factors to extension work, a five point likert-type were assigned and scored as follows: Strongly Agreed $(S A)=5$, Agreed $(A)=4$, Undecided $(U)=3$, Disagreed $(D)=2$, and Strongly Disagreed $(S D)=1$. These values were added to get 15 and later divided by 5 to get a cut of point of 3 . This means that variables with mean scores of 3 and above were regarded as major motivating factors while variables with mean scores below 3 were regarded as minor motivating factors to the extension work.

Descriptive statistics such as frequency counts, percentage and means were used to analyse the finding of the study. Pearson product moment correlation (ppmc) was used to test the hypothesis.

\section{RESULTSAND DISCUSSION \\ The Socio-economic Characteristics}

Majority of the respondents (81.1\%) were males. This result is similar to the finding of Adesiji (2006) who reported that there are more male extension agents in ADP. This showed that, there were more males than females extension agents in Agricultural Development Project in Nigeria. More than half $(56.6 \%)$ of the respondents were within the age of 31 to 40 years having overall mean of 38.8 years. This is an indication that agricultural extension agents in the study area were still agile and economically active to perform their extension work. Williams et al. 1984 affirmed that extension work needs people that are agile and active as the work involves a lot of energy demanding activities like travling, and carrying out a lot of demonstrations to farmers. This finding corroborates similar research conducted by Nestor \& Leary (2000) on whether extension agents' level of job satisfaction was related to age, it was revealed that intrinsic job satisfaction was higher for those in the age groups of 23 to 33 and 46 to 50 .

The majority (89.6\%) of Kwara ADP extension workers were married. About $56.6 \%$ of extension workers of KWADP were HND/B. Agric. Degree holders. This implies that agricultural extension agents in Kwara State were professionally trained and must have been performing the job 
professionally because of their initial interest in the profession before practising. Slightly below average $(42.3 \%)$ of respondents had between 1 to 5 years of experience in agricultural extension work. Despite the few number of years of work experience among the majority, they must have known factors that motivate them on the job. Oladele and Mabe (2010) reported that work experience was a determinant for agricultural extension job satisfaction.

\section{Table 1: The Socio-economic Characteristics of Respondents ( $n=106)$}

\begin{tabular}{|c|c|c|}
\hline Variables & Frequency & Percentage \\
\hline \multicolumn{3}{|l|}{ Gender } \\
\hline Female & 20 & 18 \\
\hline Male & 86 & 81.1 \\
\hline Total & 106 & 100.0 \\
\hline \multicolumn{3}{|l|}{ Age (years) } \\
\hline$<30$ & 12 & 1.1 .3 \\
\hline $31-45$ & 60 & 56.6 \\
\hline $46-60$ & 34 & 32.1 \\
\hline$>60$ & $=$ & - \\
\hline Total & 106 & 100.0 \\
\hline \multicolumn{3}{|l|}{ Marital Status } \\
\hline Single & 9 & 8.5 \\
\hline Married & 95 & 89.6 \\
\hline Widowed & 1 & 0.9 \\
\hline Divorced & 1 & 0.9 \\
\hline Total & 106 & 100.0 \\
\hline \multicolumn{3}{|c|}{ Educational level } \\
\hline OND & 30 & 28.3 \\
\hline HND/B. Agric & 60 & 56.6 \\
\hline Others & 16 & 15.1 \\
\hline Total & 106 & 100.0 \\
\hline \multicolumn{3}{|c|}{ Years of Extension Experience } \\
\hline $1-5$ & 45 & 42.3 \\
\hline $6-10$ & 25 & 23.6 \\
\hline $11-15$ & 7 & 6.6 \\
\hline $16-20$ & 4 & 3.8 \\
\hline $21-25$ & 7 & 6.6 \\
\hline$>25$ & 18 & 17.0 \\
\hline Total & 106 & 100.0 \\
\hline
\end{tabular}




\section{Job Motivation factors}

Results showed that factors that motivate the extension agents on their job were supervision (mean score $=4.419$ ), recognition for good work (mean=4.375), feedback from supervision (mean=4.360), evaluation of work (mean=4.355), salary increment (mean=4.320), meeting with supervisor (mean=4.236), promotion prospect (mean=4.311), annual leave opportunity (mean=4.000), payment at the right time (mean=3.693), good housing opportunity (mean=3.153) and I am more motivated by the pay than by the work I do (2.979). For supervision to be more perceived,Block Extension Supervisors (BES) must have been supportive to Village Extension Agents in delivering their duty. The supervisors are therefore considered the key factors for motivating the Village Extension Agent who are on field. This finding corroborates with Deci et al. (2001) who reported that employees who perceive that their Supervisors adopt autonomy-supportive behaviours show greater job satisfaction and higher psychological well-being than those who feel controlled by their supervisor. Other factors perceived by the respondents such as recognition for good work, annual leave opportunity, salary increments and feedback from Supervision have been supported by Olajide (2000), who stated that one way managers can stimulate motivation is to give relevant information on the consequences of their actions on others. Moreover, Akintoye (2000) asserted that money remains the most significant motivational strategy. This is because, money has the power to attract, retain and motivate individuals to higher performance. This finding is also in line with Ajayi and Banmeke (2006) who reported that the most important motivational factors influencing job performance of agricultural extension agents in Edo State Nigeria include promotion opportunity. 
Table 2: Job Motivation Factors of Respondents

\begin{tabular}{|c|c|c|c|c|c|c|c|c|}
\hline & Perceived Motivational factors & 1 & 2 & 3 & 4 & 5 & Mean & S.D \\
\hline 1. & Recognition for good work & 1.9 & 0.9 & 3.8 & 58.3 & 34.9 & 4.375 & 0.525 \\
\hline 2. & $\begin{array}{l}\text { Evaluation of my work motivates me to work } \\
\text { more. }\end{array}$ & & 1.9 & 2.8 & 51.9 & 41.5 & 4.355 & 0.637 \\
\hline 3. & $\begin{array}{l}\text { Feed back of my S upervisor increases my } \\
\text { motivation. }\end{array}$ & & & 2.8 & 54.7 & 36.8 & 4.360 & 0.542 \\
\hline 4. & $\begin{array}{l}\text { I enjoy meetin g my Supervisor to discuss my } \\
\text { work }\end{array}$ & & 0.9 & 4.7 & 45.3 & 48.7 & 4.236 & 0.737 \\
\hline 6. & Does supervision raise my performance? & 1.9 & & 6.6 & 59.4 & 32.1 & 4.419 & 0.632 \\
\hline$\overline{7}$ & $\begin{array}{l}\text { Frequently receive d positive re-organization for } \\
\text { work good. }\end{array}$ & & 4.7 & 10.4 & 53.8 & 24.5 & 3.160 & 1.324 \\
\hline 8. & $\begin{array}{l}\text { I am more mot ivated by the pay than by the } \\
\text { work I do. }\end{array}$ & $\begin{array}{l}17 . \\
9\end{array}$ & 17.9 & 17.9 & 25.5 & 13.2 & 2.979 & 1.354 \\
\hline$\overline{9}$ & $\begin{array}{l}\text { Payment at the right time is the most important } \\
\text { thing to me. }\end{array}$ & 4.7 & 16.0 & 8.5 & 44.3 & 24.5 & 3.693 & 1.158 \\
\hline 10 & $\begin{array}{l}\text { Good housing opportunity increases my } \\
\text { motivation to work. }\end{array}$ & 9.4 & 24.5 & 17.9 & 23.6 & 17.0 & 3.153 & 1.287 \\
\hline 11. & Salary increments further motivate me. & & & 2.8 & 54.7 & 36.8 & 4.320 & 0.634 \\
\hline 12 & $\begin{array}{l}\text { Better promotion prospects increase my } \\
\text { motivation. }\end{array}$ & & 1.9 & 4.7 & 50.0 & 40.6 & 4.311 & 0.741 \\
\hline 13. & Increased responsibility increases my motivation & & 0.9 & 5.7 & 50.0 & 37.7 & 3.919 & 0.888 \\
\hline 14. & Annual leave opportunity motivates me more. & 0.9 & 5.7 & 9.4 & 57.5 & 23.6 & 4.000 & 0.817 \\
\hline
\end{tabular}

Note: Strongly Agreed $(S A)=5$, Agreed $(A)=4$, Undecided $(U)=3$, Disagreed $(D)=2$, and Strongly Disagreed $(S D)=1$.

\section{Testing of hypothesis hypothesis}

$\mathrm{HO}_{1}$ : there is no significant relationship between selected socio-economics and perceived job motivational factors of extension workers of KwaraADP.

The summary of Pearson's moment correlation analysis results illustrated in Table 3 showed that age, gender, educational level and year of experience were significantly related perception of job 
motivation among the extension workers of Kwara state ADP. Similar correlate relationship between farmers' experience and their perception were found significant (Adisa and Badmos, 2009).

Table 3: Testing the Relationship between the Socio-economic Characteristics and Job Motivations

\begin{tabular}{|l|l|l|l|}
\hline Personal characteristics & $R($ value $)$ & $P($ value $)$ & Remarks \\
\hline Age & 0.854 & 0.025 & Significant \\
\hline Gender & 0.765 & 0.032 & Significant \\
\hline Education level & 0.770 & 0.025 & Significant \\
\hline Year of experience & 0.770 & 0.032 & Significant \\
\hline
\end{tabular}

Note: $R=$ Pearson correlation, $P=$ significant value, $=$ Alpha $=0.05$. Decision rule: if $\mathrm{P}>$ we accept $\mathrm{H}_{0}$

\section{CONCLUSION}

Based on the findings of this study, the study concluded that the major perceived motivating factors among extension agents in Kwara State in descending order were the following; supervision of work, recognition for good work, feedback from supervision, evaluation of work, salary increment, meeting with supervisor, promotion prospect, annual leave opportunity, payment of salary at the right time, and good housing opportunity while motivation by pay than money was considered as minor motivating factor.

In order to retain and improve performance of extension agents in the study area, the study recommended that staff members who perform supervisory role (Block Extension Supervisors) in the organization should be given more training that place more emphasis on supervision that is supportive and not controlling of field extension agent. Also, Organization's strengthening strategies such as recognition for good work, annual leave opportunity and salary increment should not be denied as at when due. 


\section{REFERENCES}

Adefalu, L.L., Ogunlade, I., Oladipo, F.O. and Adeyemo, M.A. (2011) "Youth Development Agents' Need: Challenges for Extension Volunteer Management Competencies in Nigeria" Agrosearch Journal, 11(1\&2): 69-82.

Adesiji, G. B. (2006) "Training Needs of Agricultural Extension Agents in Agricultural Development Programmes of Selected States of South Western Nigeria". Journal of Agricultural Extension, 9: 31-37.

Adesiji, G. B., Olujide, M. G., Adesiji, Y. O., Orogun, O. P. and Komolafe, S. E. (2013) "Comparative Analysis of Public and Private Veterinary services delivery among Commercial Poultry Farmers in Delta State, Nigeria". Journal of Sustainable Development in Africa, 15(7): 12-28.

Adisa, RS and Badmos AHA (2009) "Socioeconomic Correlates of Perceptions of Sustainability of Pastoral Livelihood among Cattle Herdsmen in Kwara State, Nigeria". Agrosearch Journal, 10(1\&2): 21-30

Agbamu, J. U. (2005) "Problems and prospects of agricultural extension service in developing countries.In: SF Adedoyin (Ed.): Agricultural Extension in Nigeria". Agricultural Extension Society of Nigeria, pp. 159

Ajayi, M. T., Banmeke, T. O. (2006) "Attitudinal and motivational factors influencing job performance of female extension agents in Edo State, Nigeria". South African Journal of Agricultural Extension, 35 (2): 188-198.

Akinsorotan, A. O., Adesiji, G. B. (2001) "Analysis of Motivational Factors on Job Performance of Village Extension Agents in Oyo State, Nigeria". Journal of Advanced Studies in Educational management, 1 (1): 135-141.

Akintoye, I. R. (2000) "The place of financial management in personnel psychology. A Paper Presented as Part of Personnel Psychology Guest Lecture Series, Department of Guidance and Counselling, University of Ibadan, Nigeria

Babu, A. R., Singh Y., Sachderva, P. (1997) "Managing Human Resources within Extension, In: Burton E. Swanson, RobertP. Bentz, Andrew J. Sofranko (eds), Improving Agricultural extension". A reference manual Food and Agriculture Organization of the United Nations, Rome

Bakker, A. B., Albrecht S., and Leiter M. P. (2011) "Work engagement: Further reflections on the state of play". European Journal of Work and Organizational Psychology, 20:74-88 Banmeke, T. O. and Ajayi, M. T. (2005) "Job satisfaction of Extension Workers in Edo State Agricultural Development Programme (EDADP) Nigeria" International journal of Agricultural and Rural Development,6: 202-207.

Deci, E. L., Ryan, R. M., Gagne, M., Leone, D. R., Usunov, J. and Kornazheva, B. P. (2001) "Need satisfaction, motivation, and well-being in the work organizations of a former Eastern Bloc country". Personality and Social Psychology Bulletin, 27: 930-942. 
Haile, M. G., Abebaw, D. (2012) "What Factors Determine the Time Allocation of Agricultural Extension Agents on Farmers' Agricultural Fields? Evidence from Rural Ethiopia”. J. Agric. Ext. and Rural Dev. 4 (10):318-329.

Idachaba, F. A. (1984) "Productivity Management", A practical Handbook, International Labour organization. 209pp

Ifenkwe, G. E. (2012) "Agent-Related Factors Affecting the Performance of Agricultural Extension Staff in Abia State, Nigeria". JAgri Sci, 3 (1): 45-48.

Madukwe, M. C. (1996) "Restructuring Field Agricultural Extension Services in Nigeria: Issues and Options in Sustainable Rural Development" Proceedings of AgriculturalExtension of Nigeria (AESON) Conference,Ago Iwoye, Ogun State University. 314pp

Mojoyinola, J. K. (2000) "Psychological Strategies for Motivating Patients Back to Health". Nigerian Journalof Social Work, 4: 53-64.

Nestor, P. I., and Leary, P. (2000) "The Relationship between Tenure and Non-tenure Track Status of Extension Faculty and Job Satisfaction".Journal of Extension, 38(4). From http://www.joe.org/joe/2000august/rb1.html

Oladele, O. I. and Mabe L. K. (2010) "Socio-economic Determinants of Job Satisfaction among Extension Officers in North West Province South Africa" Life Science Journal, 7 (3): 99 104.

Olagunju, F. I. and Adesiji, G. B. (2011) "Impact of Agricultural Extension Services on Cocoyam Production in Ogun State, Nigeria" Journal of Agricultural \& Food Information, 12 (34): 294-303.

Olajide, A. (2000) "Getting the Best out of the Employees in a Developing Economy". A Personnel Psychology Guest Lecture Series, Department of Guidance and Counselling, University of Ibadan, Nigeria

Ployhart, R. E. (2006) "Staffing in the 21st century: New Challenges and Strategic Opportunities" Journalof Management, 32: 868-879. 